\title{
Increasing Teacher Performance through Strengthening School Principal's Visioner Leadership, Teamwork and Personality of High School Teachers
}

\author{
Martinus Gea ${ }^{\# 1}$, Soewarto Hardhienata ${ }^{* 2}$, Rita Retnowati ${ }^{\# 3}$

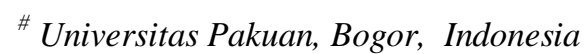 \\ Jl. Pakuan, RT.02/RW.06, Tegallega, Kecamatan Bogor Tengah, Kota Bogor, Jawa Barat 16129
}

\begin{abstract}
This study aims to find efforts to improve teacher performance through the development of variables that have a relationship with teacher performance, namely visionary leadership, teamwork and personality with the first step researching the strength of the relationship between research variables, the strength of the relationship between visionary leadership and teacher performance. between teamwork and teacher performance. The strength of the relationship between personality and teacher performance. The strength of the relationship of visionary leadership and teamwork together with teacher performance. The strength of the relationship of visionary leadership and personality together with teacher performance. The strength of the relationship of teamwork and personality together with teacher performance. The strength of the relationship of visionary leadership, teamwork and personality together with teacher performance. The population of this research is the teachers of ASN SMA Negeri in Tangerang City totaling 453 people from 12 SMA Negeri. The sampling technique used is a random sampling technique (proportional random sampling). Samples were taken using the Slovin formula with a sampling error rate of 5\%. The results of the calculation of the number of samples are 213 people. The research method uses quantitative methods with quantitative analysis. The results of the study show that there is a positive and very significant relationship between the principal's visionary leadership and teacher performance, there is a positive and very significant relationship between teamwork and teacher performance, there is a positive and very significant relationship between personality and teacher performance.
\end{abstract}

Keywords - Teacher Performance, Teamwork, Personality

\section{INTRODUCTION}

Development is a continuous process that covers all aspects of people's lives, including social, economic, political and cultural aspects with the main objective of improving the welfare of the nation's citizens as a whole. According to Law No. 20 of 2003 concerning the National Education System that in the process of sustainable development, the role of education is very strategic. Based on the strategic role of education in development, it is not surprising that then the government and society give considerable attention to the problem of education. The great concern of the government and the community is one of them seen in the effort to create a society that can receive education equally, meaning that both the government and the community seek educational facilities in the form of schools or madrasas from basic education to secondary education, so that with these facilities the community can enjoy the learning process. education in a formal institution.

In an effort to educate the nation's life, teachers who are also referred to as educators and are one of the education staff, occupy a very important position. With their professionalism and close relationship with students, teachers play a role in creating a conducive learning environment. Law number 20 of 2003 concerning the National Education System states that educators are professionals in charge of planning and implementing the learning process, assessing learning outcomes, conducting guidance and training, as well as conducting research and community service. In learning, the professionalism of teachers is reflected in their ability to make quality instructional designs or learning designs before holding meetings with their students. The teacher's ability to make instructional designs will greatly affect the students' abilities, especially the learning outcomes to 
DOI: $\underline{10.51386 / 25815946 / \mathrm{ijsms}-\mathrm{v} 4 \mathrm{i} 5 \mathrm{p} 117}$

Volume: 4 Issue: 5

September to October 2021

https://www.ijssmsjournal.org

be achieved. So the professional task of teachers which is very important and very closely related to learning activities is the making of instructional designs or learning designs which every teacher must master.

The teacher is someone who is not only tasked with teaching students, but also has to educate students to become spiritually and physically intelligent individuals. Turning students into quality generations is not easy, but requires hard work and the participation of families, schools, religions, and communities. Therefore, a teacher must have various kinds of competencies as a teacher who has professional performance, namely discipline, achievement, loyalty, and responsibility. Teachers can improve their performance by doing positive things in carrying out their duties as a teacher such as teaching according to the schedule, always on time, never skipping teaching, working well with fellow teachers, being honest, and so on. Professional teachers must of course have high performance in order to produce disciplined, achievement, loyal, and responsible performance. Teachers can improve their performance by doing positive things in carrying out their duties as a teacher such as teaching according to the schedule, always on time, never skipping teaching, working well with fellow teachers, being honest, and others. Teacher performance can be defined as the extent to which a teacher works optimally according to his abilities in an effort to achieve institutional goals. The ability of a teacher will be seen at the time of teaching which can be measured from his teaching competence.

Based on the view above that teacher performance there are several characteristics, including: 1) teachers such as basic knowledge, sense of responsibility, and curiosity, 2) students such as learning opportunities and academic assignments, 3) teaching factors such as lesson structure and communication, and 4) learning aspects such as engagement and success in The presence of the teacher as one of the implementers of the Education Office program which is one part of the organization of the Regional Government, can make a strong contribution to improving the quality of education. The following is data on teacher performance in several schools in the work area of the South Tangerang City Education Office at the State Senior High School level that was collected through a preliminary survey focused on aspects of the ability to plan and prepare for teaching, mastery of the material to be taught to students, mastery of methods and teaching strategies, giving assignments to students, class management skills and the ability to conduct assessments and evaluations.

In this preliminary survey, several school principals assessed several teachers in their schools as many as 40 teachers at the South Tangerang City Senior High School. The data in the table above is the result of a preliminary survey that was successfully recapitulated. Based on the preliminary survey data above, the condition can indicate that the performance of public high school teachers in the Tangerang City Education Office is still low, so it needs to be improved to a better stage. However, the improvement in question, especially in terms of improving teacher performance, requires sufficient time because it is related to various factors that influence it. Conditions like the above can be minimized if in school life we have a visionary leadership of the principal, good teamwork and teacher personality, a cultured environmental conduciveness with good spiritual support will raise self-awareness which of course will be a good and cooperative synergy in achieving goals. school together.

Principal's visionary leadership is a complex phenomenon of social interaction, and is often difficult to read. Leadership in any organization definitely requires a leader who can understand the goals of the organization, pay attention to and fulfill the life of each individual. Principals who have visionary leadership are principals who have insight and understand the needs of their followers. The visionary principal has the idea of being able to see the future in facing challenges and solving them without any hassles. The Principal's visionary leadership holds the skills to motivate all school members, create long term partnerships with other organizations or institutions, generate suitable resources for use in institutions and no doubt, this enables organizations to change over time. This study aims to find efforts to improve teacher performance through the development of variables that have a relationship with teacher performance, namely visionary leadership, teamwork and personality with the first step researching the strength of the relationship between research variables, the strength of the relationship between visionary leadership and teacher performance. between teamwork and teacher performance. The strength of the relationship between personality and teacher performance. The strength of the relationship of visionary leadership and teamwork together with teacher performance. The strength of the relationship of visionary leadership and personality together with teacher performance. The strength of the relationship of teamwork and personality together with teacher performance. The strength of the relationship of visionary leadership, teamwork and personality together with teacher performance. 


\section{DOI: $10.51386 / 25815946 /$ ijsms-v4i5p117}

\section{METHOD}

This study uses a combination of sequential explanatory design research methods. According to Sugiyono (2011:415) the sequential explanatory design combination research method is a combination research method that combines quantitative and qualitative research methods sequentially, in the first stage the research was carried out using quantitative methods and in the second stage was carried out using qualitative methods. The research method used is a survey with a approach correlational. The research variable consisted of three independent variables, namely the visionary leadership of the principal (X1), teamwork (X2), and personality (X3), with the dependent variable being teacher performance (Y). To obtain data in the field used measuring instruments (instruments) in the form of a questionnaire that was compiled based on the indicators that exist in the research variables. The primary data needed is data on the principal's visionary leadership, teamwork and personality and teacher performance.

The problem context in this study can be seen in Figure 2

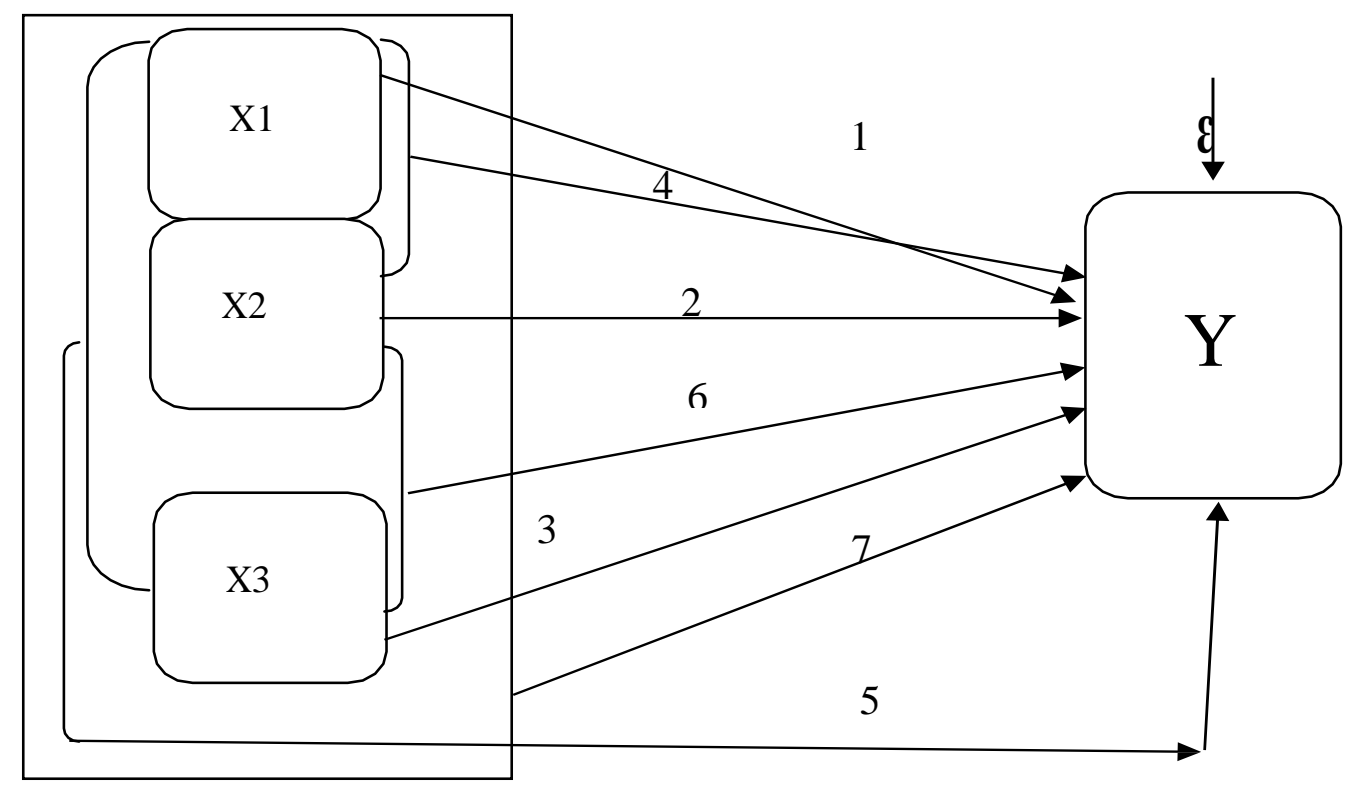

Fig 2. Research Model

Information :

X1: Principal Visionary Leadership Variable , X2: Teamwork Variable, X3: Personality Variable and Y: Teacher Performance Variable

Based on the theoretical studies and frameworks that have been described, the research hypotheses can be formulated as follows:

1. There is a positive relationship between visionary leadership and teacher performance, so that strengthening visionary leadership can improve teacher performance

2. There is a positive relationship between teamwork and teacher performance, so that strengthening teamwork can improve teacher performance

3. There is a positive relationship between personality and teacher performance, so that personality strengthening can improve teacher performance

4. There is a positive relationship between visionary leadership and teamwork together with teacher performance, so that strengthening visionary leadership and teamwork together can improve teacher performance

5. There is a positive relationship between visionary leadership and personality together with teacher performance, so that strengthening visionary leadership and personality together can improve teacher performance

6. There is a positive relationship between teamwork and personality together with teacher performance, so that strengthening teamwork and personality together can improve teacher performance 
DOI: $\underline{10.51386 / 25815946 / \mathrm{ijsms}-\mathrm{v} 4 \mathrm{i} 5 \mathrm{p} 117}$

Volume: 4 Issue: 5

September to October 2021

https://www.ijsmsjournal.org

7. There is a positive relationship between visionary leadership, teamwork and personality together with teacher performance, so that strengthening visionary leadership, teamwork and personality together can improve teacher performance

The population of this study were teachers of State High School (SMAN) in South Tangerang City with the status of State Civil Apparatus (ASN), totaling 453 people from 12 schools. The data of ASN teachers were taken as the population in this study on July 5, 2018. The sampling technique used is a random sampling technique (proportional random sampling), this technique is used because the population has heterogeneous members/elements and the population is large. The sample is part of the number and characteristics possessed by the population. Based on the results of calculations from Slovin, the population studied was 213 people. The sampling technique used proportional random sampling technique by taking into account the proportion of the population in each school.

\section{III.RESULT AND DISCUSSION}

\section{The Relationship between Principal's Visionary Leadership and Teacher Performance}

Research results for the principal's visionary leadership instrument obtained a median value of 136, far above the theoretical median of 75, indicating that the principal's visionary leadership is good. On the other hand, the results of the significant correlation test between the principal's leadership and teacher performance obtained the value of tcount $=29,035$ which is greater than the value of ttable $=1.6525$ which indicates there is a significant relationship between the visionary leadership of the principal and teacher performance.

Based on the results of the research by testing the hypothesis, the value of the simple linear correlation coefficient between the visionary leadership of the principal and the teacher's performance (ry1) is 0.894 . The probability value is $0.000<0.05$, then Ho is rejected, so it can be concluded that the correlation coefficient is significant. Thus, this study confirms that independently there is a significant relationship between the principal's visionary leadership and teacher performance. The results of this study get the equation $=-28.977+$ $1.098 \mathrm{X} 1 \mathrm{can}$ be used to predict teacher performance based on the school principal's visionary leadership score, it can be predicted that every 1 increase in the principal's leadership score will increase teacher performance by 1.098 times at a constant - 28.977 .

The results of the calculation (analysis) are quantitatively strengthened by findings and qualitative analysis which states that principals who have a vision will make it easier for teachers to make work programs. Visionary principals provide measurable and clear directions for school goals, this is able to improve teacher performance. The results of observations in schools show that the principal is always optimistic, dares to take risks and is responsible. For example, the planned idea turned out to require a lot of funds. Seeing this situation, the principal will automatically be responsible for making funding run smoothly, whether it is applying for funding or even borrowing money. He did this in order to realize the idea he had planned from the start. This optimistic attitude, dare to take risks and be responsible is able to make teachers have a high level of trust in leaders which leads to increased teacher motivation to work optimally so that teacher performance increases. Based on the description above, the visionary leadership of the principal independently is one of the determining factors in improving teacher performance at SMA Negeri Tangerang Selatan.

\section{Relationship between Teamwork and Teacher Performance}

The results of descriptive statistics for teamwork instruments obtained a median value of 139 , far above the theoretical median of 98, indicating that the teamwork of SMAN Tangerang Selatan teachers was good. On the other hand, the results of the significant correlation test between teamwork and teacher performance obtained the value of tcount $=18,184$ which is greater than the value of ttable $=1.6525$ which indicates that there is a significant relationship between teamwork and teacher performance. The results of the simple correlation research show that there is a significant relationship between teacher teamwork and teacher performance, meaning that teachers who have good teamwork will have an impact on high performance. The strength of the relationship between teamwork and teacher performance is reflected in the ry2 correlation coefficient of 0.781 . The diversity in teacher performance related to personality is reflected in the coefficient of determination of 0.610 or $61.0 \%$, while the remaining $39.0 \%$ is influenced by other factors. The results of this study get the equation $=-1.264+0.871 \mathrm{X} 2$ can be used to predict teacher performance based on teamwork scores, it can be 
DOI: $\underline{10.51386 / 25815946 / \mathrm{ijsms}-\mathrm{v} 4 \mathrm{i} 5 \mathrm{p} 117}$

Volume: 4 Issue: 5

September to October 2021

https://www.ijsmsjournal.org

predicted that every 1 increase in teamwork score will increase teacher performance by 0.871 times at a constant $-1.264$.

The quantitative data above is strengthened by the observational data of qualitative research which concludes that qualitative teamwork in the field has the same tendency as teamwork in quantitative research. Some findings in the field (schools) show that schools with good subject teacher deliberations (MGMPs) have better teacher performance than schools whose MGMPs do not work. Schools that regularly hold regular meetings between personnel to share knowledge and discuss problem solving for a solution have teacher performance that continues to improve from time to time. Based on the description above, teamwork is one of the determining factors in improving teacher performance.

\section{The Relationship between Teacher Personality and Teacher Performance}

The results of descriptive statistics for the teacher's personality instrument obtained a median value of 110, far above the theoretical median of 93, indicating that the teacher's personality at SMA Negeri Tangerang Selatan was good. On the other hand, the results of the significant correlation test between teamwork and teacher performance obtained the value of tcount $=73.770$, which is greater than the value of ttable $=1.6525$ which indicates that there is a significant relationship between the teacher's personality and teacher performance. The results of calculations and analysis of simple correlation research show that there is a significant relationship between the teacher's personality and teacher performance, it can be interpreted that teachers who have good personalities will have high performance. The strength of the relationship between teacher personality and teacher performance is reflected in the correlation coefficient value of 0.981 . The diversity in teacher performance related to personality is reflected in the coefficient of determination of 0.963 or $96.3 \%$, while the remaining $3.7 \%$ is influenced by other factors.

The results of this study get the equation $=60.041+0.554 \mathrm{X} 3$ can be used to predict teacher performance based on the teacher's personality score, it can be predicted that every 1 increase in the teacher's personality score will increase teacher performance by 0.554 times at a constant 60.041.Direct supervision in schools for qualitative research observations that have obtained several findings including good teacher manners, friendly, caring for students and serving every learning with dedication, showing the teacher's personality in general is very good. Almost all the students who interviewed gave the answer that they were happy and guided by the teachers at school, this shows that the teachers of SMA Negeri Tangerang Selatan have good personalities. Based on the description above, it can be concluded that the teacher's personality is one of the determinants of the performance of the SMA Negeri Tangerang Selatan city teacher.

\section{Relationship Principal Visionary Leadership and Teamwork with Teacher Performance}

The results of statistical descriptive data processing for the variables of the principal's visionary leadership and teamwork showed medians of 135 and 136 which were far above the theoretical median. The statistical descriptive results of these two independent variables are in line with the descriptive results of the dependent variable Teacher Performance which also obtained a median value of 121 which is far above the theoretical media value of 80 . This statistical descriptive result reflects that the principal's visionary leadership and high teamwork will improve teacher performance to be high. Based on the results of hypothesis testing with regression testing, the value of Fcount $=555.367$ is greater than Ftable $=2.65$. The results of this significance test indicate that there is a positive relationship between the principal's visionary leadership and teamwork with teacher performance. At the South Tangerang City Senior High School, if they have good teamwork, the teacher's performance will be good.

The results of the calculation to find out the level of the relationship between the independent and dependent variables, the correlation coefficient value of the relationship between the principal's visionary leadership and teamwork with teacher performance (ry12) is 0.917 , with a probability value (sig) $0.000<0.05$ then Ho is rejected, meaning there is a leadership relationship. visionary principal and teamwork with teacher performance. Thus, this study confirms that there is a relationship between the principal's visionary leadership and teamwork with teacher performance. The results of this study are in line with Hersey and Blanchard's theory that there are four main leadership styles: Telling/directing, the leader tells members of the organization what to do and how to do it; Selling/Coaching, leaders provide information and direction, but there is more communication with followers; Participating/consulting, the leader focuses more on relationships and less on direction. Leaders work with teams, and share decision-making responsibilities; Delegating, the leader passes 
DOI: $\underline{10.51386 / 25815946 / \mathrm{ijsms}-\mathrm{v} 4 \mathrm{i} 5 \mathrm{p} 117}$

Volume: 4 Issue: 5

September to October 2021

https://www.ijsmsjournal.org

most of the responsibility on to followers or groups. Leaders still monitor progress, but they are less involved in decisions.

Based on the description above, the principal's visionary leadership and teamwork are the determining factors in improving the performance of the teachers of SMA Negeri Tangerang Selatan. This is reinforced by the results of quantitative research and focuses on the fourth qualitative research, namely: which of the two independent variables, namely the visionary leadership of the principal and teamwork is more dominant in relation to teacher performance. reinforced by qualitative data that teamwork is more dominant in influencing teacher performance than the visionary leadership of the principal.

\section{The relationship of Principal Visionary Leadership and Teacher Personality with Teacher Performance.}

The results of statistical descriptive data processing for the variables of visionary leadership and teacher personality show medians of 135 and 1110 which are far above the theoretical median, this gives an illustration that the visionary leadership of the principal and the personality of the teachers of SMA Negeri Tangerang Selatan is good. The statistical descriptive results of these two independent variables are in line with the descriptive results of the dependent variable on teacher performance which also obtained a median value of 121 which is far above the theoretical median value of 80 . These statistical descriptive results reflect that the principal's visionary leadership and high teacher personality will increase teacher performance to be high. .

Based on the results of hypothesis testing with regression testing, the value of Fcount $=2716,754$ is greater than Ftable $=2.65$. The results of this significance test indicate that there is a positive relationship between the principal's visionary leadership and the teacher's personality with teacher performance. good and the teacher at the South Tangerang City Public High School has a good personality, the teacher's performance will be good. The results showed that there was a significant positive relationship between the principal's visionary leadership and the teacher's personality with teacher performance. Based on the results of the study, the correlation coefficient value of the relationship between the principal's visionary leadership and the teacher's personality with (ry13) was 0.981 , with a probability value (sig) of $0.000<0.005$, then Ho was rejected, meaning that there was a significant relationship between the principal's visionary leadership and the teacher's personality with performance. teacher. Thus, this study confirms that there is a significant positive relationship between the principal's visionary leadership and the teacher's personality with teacher performance. The contribution of the principal's visionary leadership and the teacher's personality to the teacher's performance (r2y13) is 0.967 which can be interpreted as $96.7 \%$ diversity in teacher performance can be explained by the principal's visionary leadership and teacher personality. Based on the description above, the principal's visionary leadership and teacher's personality are the determining factors for the performance of SMA Negeri teachers in South Tangerang. This is reinforced by the results of quantitative research and focuses on the fifth qualitative research, namely: which of the two independent variables, namely the visionary leadership of the principal and the teacher's personality, is more dominant in relation to teacher performance, obtained information based on quantitative data through the results of the partial correlation test which reinforced by qualitative data that personality is very dominant in influencing teacher performance than the visionary leadership of the principal. The partial correlation results show that the relationship between the principal's visionary leadership and teacher performance with the control variables of teamwork and personality has no significant effect, it can be concluded that the relationship between the teacher's personality variable and teacher performance is more dominant than the relationship between the principal's visionary leadership and teacher performance. The correlation value of the principal's visionary leadership and teacher's personality with teacher performance (ry13) of 0.981 is exactly the same as the simple correlation value of teacher's personality with teacher performance (ry3 $=0.981)$ indicating that the principal's visionary leadership variable has no significant relationship with teacher performance.

\section{The relationship between Teamwork and Teacher Personality with Teacher Performance.}

Based on the results of hypothesis testing with the variable regression test of teamwork and teacher's personality with teacher performance, the value of Fcount $=3032,694$ is greater than Ftable $=2.65$. The results of this significance test indicate that there is a positive relationship between teamwork and teacher personality with teacher performance, which means working teamwork. well supported by a healthy teacher personality will increase teacher performance to be good. The results showed that there was a significant positive relationship 
DOI: $\underline{10.51386 / 25815946 / \mathrm{ijsms}-\mathrm{v} 4 \mathrm{i} 5 \mathrm{p} 117}$

Volume: 4 Issue: 5

September to October 2021

https://www.ijsmsjournal.org

between teamwork and teacher personality with teacher performance. Based on the results of the study, the correlation coefficient of the relationship between teamwork and personality with teacher performance (ry23) was 0.983 , with a probability value (sig) $0.000<0.05$, then $\mathrm{Ho}$ was rejected, meaning that there was a relationship between teamwork and teacher personality with teacher performance. Thus, this study confirms that there is a significant positive relationship between teamwork and teacher personality with teacher performance.

The correlation coefficient of 0.983 according to the Guilford category is classified as very high, which means that it has a very high correlation. The diversity in the performance of SMA Negeri Tangerang Selatan city teachers can be explained due to the influence of teamwork and the teacher's personality obtained from the coefficient of determination of 0.967 , which it is interpreted that $96.7 \%$ of the performance factors of SMA Negeri Tangerang Selatan city teachers are jointly influenced by teamwork and teacher personality.

Based on the description above, the principal's visionary leadership, teamwork and teacher personality are the determining factors in improving the performance of SMA Negeri teachers in South Tangerang City. This is reinforced by the results of quantitative research and focus on the sixth qualitative research, namely: which of the two independent variables, namely teamwork and personality, is more dominant in relation to teacher performance, obtained information based on quantitative data through partial correlation tests which are strengthened by data. Qualitatively, the teacher's personality has a more dominant relationship with teacher performance compared to teamwork, although both significantly determine the relationship with teacher performance.

Teacher performance is a reflection of the success of excellent service from schools to the community. Good teacher performance indications are the level of satisfaction of students and parents in getting services both in the form of direct teaching and services outside of teaching. The form of excellent service from schools requires team alignment from schools to synergize with each other in improving services to students and the community. Good teamwork will increase the synergy between teachers to share and complement each other in providing services. Schools with good teamwork supported by healthy, open individuals with high dedication will have a tremendous impact on the level of community satisfaction as a form of real indicator of teacher performance.

\section{Mutual Relationship Principal Visionary Leadership, Teamwork and Teacher Personality with Teacher Performance.}

Based on the results of hypothesis testing with variable regression test of principal visionary leadership, teamwork and teacher personality with teacher performance, the value of Fcount $=2013,096$ is greater than Ftable $=2.65$. The results of this significance test indicate that there is a positive relationship between the principal's visionary leadership, teamwork and the teacher's personality with teacher performance is defined as the ability of the principal in looking forward to be poured in a structured school work program, good teamwork supported by a healthy teacher personality will improve teacher performance to be good. The results showed that there was a significant positive relationship between the principal's visionary leadership, teamwork, and teacher personality with teacher performance. Based on the results of the hypothesis test, the correlation coefficient of the relationship between the principal's visionary leadership, teamwork, and teacher personality with teacher performance (ry123) is 0.983 , with a probability value (sig) $0.000<0.05$, then Ho is rejected, meaning that there is a significant positive relationship with visionary leadership. principal, teamwork, and teacher personality with teacher performance. Thus, this study confirms that there is a significant relationship between the principal's visionary leadership, teamwork, and teacher personality with teacher performance.

Based on the description above, the principal's visionary leadership, teamwork and personality are the determining factors for the performance of SMA Negeri teachers in South Tangerang.

$\mathrm{T}$ the correlation between teacher performance and the visionary leadership of the principal is equal to 0.894 which is categorized as strong, but if it is seen the partial correlation value of 0.021 is very weak (not significant). This figure (partial correlation) is the number of correlation coefficients after the influence of the teamwork and teacher personality variables is removed from the relationship with teacher performance. This figure shows the actual number of correlation coefficients in the relationship between the dependent variable of teacher performance and the independent variables of visionary leadership, teamwork and teacher personality. 
DOI: $\underline{10.51386 / 25815946 / \mathrm{ijsms}-\mathrm{v} 4 \mathrm{i} 5 \mathrm{p} 117}$

Volume: 4 Issue: 5

September to October 2021

https://www.ijssmsjournal.org

Furthermore, if the part correlation between the teacher performance variable and the visionary leadership of the high school principal is 0.04 after the influence of the teamwork and teacher personality variables is removed. So based on table 4.39 it shows that of the three independent variables only two independent variables have a significant effect, namely the teamwork and teacher personality variables, this is also in accordance with the results of the partial correlation test of the principal's visionary leadership with teacher performance which shows a sig value of $0.761>0$, 05 (not significant). Then consistently with regression analysis shows that sequentially from the largest is the teacher's personality variable, then the teamwork variable, this can be seen from the number of partial correlation and part correlation

Based on the above analysis, it can be concluded that although together there is a significant relationship between the principal's visionary leadership, teamwork and teacher personality with teacher performance, partially only the teamwork and teacher personality variables are significant determinants of teacher performance. The results of this study can explain that good teacher performance begins with the ability of a school principal to see the future that the school will aim for. Principals who have a good vision will dare to take risks and be responsible for continuously running programs that have been made with the school team. Partially more influential on teacher performance is teamwork and teacher personality, this shows that teamwork is a picture of the synergy between all components in the school which is a form of cooperation from all human resources in the school in carrying out school programs with the direction and coordination of the principal. . Good teamwork must be created by a principal who has a vision and is supported by teachers with healthy personalities. The three independent variables, namely the visionary leadership of the principal, teamwork and the personality of the teacher are a mutually supportive combination to improve teacher performance.

\section{CONCLUSIONS}

There is a positive relationship between visionary leadership and teacher performance, so that strengthening visionary leadership can improve teacher performance. There is a positive relationship between teamwork and teacher performance, so that strengthening teamwork can improve teacher performance. There is a positive relationship between personality and teacher performance, so personality strengthening can improve teacher performance. There is a positive relationship between visionary leadership and teamwork together with teacher performance, so that strengthening visionary leadership and teamwork together can improve teacher performance. There is a positive relationship between visionary leadership and personality together with teacher performance, so that strengthening visionary leadership and personality together can improve teacher performance There is a positive relationship between teamwork and personality together with teacher performance, so that teamwork and personality are strengthened together can improve teacher performance There is a positive relationship between visionary leadership, teamwork and personality together with teacher performance, so that strengthening visionary leadership, teamwork and personality together can improve teacher performance. Improving Teacher Performance through Principal Visionary Leadership If teacher performance is to be improved, it is necessary to strengthen the principal's visionary leadership. Improving Teacher Performance through Teamwork If teacher performance is to be improved, it is necessary to strengthen teamwork. Teacher Performance Improvement through Personality. If the teacher's performance is to be improved, it is necessary to strengthen the personality. Improvement of the Teacher's Performance through the Principal's Visionary Leadership and Teamwork. Improving Teacher Performance through Principal Visionary Leadership and Personality If teacher performance is to be improved, it is necessary to jointly strengthen the principal's visionary leadership and personality. Teacher performance improvement through Teamwork and Personality. If the teacher's performance is to be improved, it is necessary to strengthen teamwork and personality together. Effectiveness of Nurse Performance through Principal's Visionary Leadership, Teamwork and Personality If nurses' performance is to be improved, it is necessary to jointly strengthen the principal's visionary leadership, teamwork and personality. The results of this study indicate that there is a positive relationship together with the principal's visionary leadership, teamwork and teacher personality with teacher performance. These results provide input that the performance of the SMA Negeri Tangerang Selatan city teachers can be improved by increasing the three determinants, namely the principal's visionary leadership, teamwork and teacher personality. The teacher's personality is the variable determining the level of teacher performance with the greatest significance being the first target that must be considered. The high teacher personality of the teacher will result in the level of teacher performance. For this reason, the school or education office needs to take training steps to change the teacher's personality so that it is more optimal. Good teamwork will result in good teacher performance, for that it is necessary to take steps to make outbound training policies 


\section{DOI: $10.51386 / 25815946 / \mathrm{ijsms}-\mathrm{v} 4 \mathrm{i} 5 \mathrm{p} 117$}

Volume: 4 Issue: 5
September to October 2021

\section{https://www.ijsmsjournal.org}

so that teacher teamwork is more solid, so that the level of work suitability for work is optimal. The ability to work together in an effective team will improve overall performance. The principal's visionary leadership, although partially does not have a significant relationship with the level of teacher performance, but together with other variables has a relationship with the level of teacher performance. For this reason, it is necessary for school principals to improve their visionary abilities so that teacher performance can increase by means of school management conducting training to principals to improve their visionary abilities.

\section{REFERENCES}

[1] A Kusumaningtyas, E Setyawati - International Journal of Evaluation and Research in Education. 2015

[2] Aan Komariah dan Cepi Triatna.Visionary Leadership Menuju Sekolah Efektif. Jakarta: Bumi Aksara. 2016

[3] Abdul Majid, Dian Andayani. Pendidikan karakter dalam perspektif Islam.Bandung: Insan Cita Utama. 2010.

[4] Anwar Prabu Mangkunegara. Manajemen Sumber Daya Manusia.Bandung: PT. Remaja Rosdakarya. 2011.

[5] Andrew J. DuBrin. Essensial of Management. Mason: Cengage Learning. 2009 Armstrong, Michael and Stephen Taylor. Armstrong's Handbook of Human Resource Management Practice. Kogan Page. 2014.

[6] Blanchard, Ken \& Hersey, Paul, 1977. Management of Organizational Behavior, Englewood Cliffs, New Jersey: Prentice -Hall, Inc.

[7] Beddu, A., Suaib, D., Jennah, M. 2016. "Pengaruh Kepemimpinan Visioner Kepala Sekolah Terhadap Kinerja Guru SMP Negeri 12 Sigi”. eJurnal Katalogis, Vol. 4, No. 7, Juli 2016.

[8] Benny A. Pribadi. Model Desain Sistem Pembelajaran.Jakarta: Dian Rakyat.2009.

[9] Cecilia Irungu and Josphat Kagema. Teacher Performance. International Journal of Education Vol. 11 No. 1, Agustus 2018.

[10] Chamundeswari. International Journal of Academic Research in Business and Social Sciences, Job Satisfaction and Performance of School Teachers. 2008

[11] Chantathai, P., Tesaputa, K., Somprach, K. 2015. Development of Effective Teacher Program: Teamwork Building Program for Thailand's Municipal Schools. International Education Studies Vol. 8, No. 9

[12] Colquitt, Lepine, Wesson. Organizational Behavior. McGrow Hill International Edition.2009.

[13] Organizational behavior: Improving performance andcommitment in the workplace.McGraw-Hill Irwin. 2011

[14] Danim, Sudarwan. Pengantar Kependidikan.Bandung: Alfabeta.2010. Davis.2006. Psychologymania : Indikator-indikator kerjasama, diakses dari:http://www.psychologimania.com/2013/02/indikator-indikator-kerja- sama.html. Pada tanggal 27 April 2017 pukul 19.15

[15] Dessler, Garry. Manajemen Sumber Daya Manusia. Jakarta. Indeks.2003

[16] D. E. McFarland.1970.Management: Principles and Practices.Edisi 3. Collier- Macmillan

[17] Eko Widodo, Suparno. .”Manajemen Pengembangan Sumber Daya Manusia”.Yogyakarta: Pustaka Pelajar. 2015

[18] Fatmawati, E. 2020. "Korelasi Budaya Kerja dan Teamwork Terhadap Kinerja Guru SMA Negeri Kecamatan Pinang Raya Bengkulu Utara”. Jurnal Manajemen Pendidikan, Vol. 14(2), 2020

[19] Feist, Jess dan Feist, Gregory.Teori Kepribadian. Buku 2. Jakarta: Salemba Humanika. 2010.

[20] Fransiska, W., Harapan, E., Tahrun. 2020. "Pengaruh Kepemimpinan Visioner Kepala Sekolah dan Disiplin Guru terhadap Kinerja Guru Sekolah Dasar". Journal of Education Research, 1(3), 2020.

[21] George, Jennifer and Gareth R Jones. Understanding and Managing

[22] Organizational Behavior. Pearson Education, Inc, New Jersey. 2012 Gregory, George A. Gregory's Pediatric Anesthesia.Fifth Edition. West Sussex:Blackwell Publishing.2012

[23] Hartiwi, H., Kozlova, A., Masitoh, F. 2020. The Effect of Certified Teacher and Principal Leadership Toward Teacher's Performance. International Journal of Education Review, 2(1), March 2020.

[24] Hasibuan, Malayu S.P. Manajemen Sumber Daya Manusia, Jakarta: Bumi Aksara, 2010.

[25] Ivancevich et.al.Human Resource Management (10thed).New York: McGraw Hill, Inc. 2006. 


\section{DOI: $\underline{10.51386 / 25815946 / i j s m s-v 4 i 5 p 117}$}

Volume: 4 Issue: 5

September to October 2021

https://www.ijsmsjournal.org

[26] Kartini, D., Kristiawan, M., Fitria, H. 2020. The Influence of Principal's Leadership, Academic Supervision, and Professional Competence toward Teacher's Performance. International Journal of Progressive Science and Technology, 20 (1), pp. 156-164, April 2020 .

[27] Kerrin, M. and Oliver, N. Collective and Individual Improvement Activities: the Role of Reward Systems, Personal Review vol. XXXI, no. 3.2002

[28] Khalimah, S., Soegito, A., Nurkolis. 2018. "Pengaruh Kepemimpinan Visioner Kepala Sekolah dan Kompensasi Terhadap Kinerja Guru Taman Kanak - Kanak di Kecamatan Tembalang Kota Semarang”. Jurnal Manajemen Pendidikan, Vol. 7, No.3, Desember 2018.

[29] Klassen, Cees A, Teacher pedagogical competence and sensibility “ "Teaching and Teacher Education 18. No.2, 2002.

[30] Kreitner, Robert dan Kinicki, Angelo. Perilaku Organisasi, terjemahan; Erly Suandy. Jakarta: Salemba Empat, 2005.

[31] Luthans, Frted. Organizational Behavior, Singapura: Mc Graw-Hill Book, 2005. Mangkunegara, A.A. Anwar Prabu. Manajemen Sumber Daya Manusia. Bandung: Remaja Rosda Karya. 2005.

[32] Mangkuprawira, Tb. Sjafri. Horison. Bisnis, Manajemen, dan Sumber Daya Manusia. Bogor: ITB Press. 2009

[33] Manajemen Sumber Daya Manusia Strategik. Ghalia Indonesia. Bogor.2011

[34] Manzoor, S.R., HafizUllah, Hussain, M., Ahmad, Z. Effect of Teamwork on Employee Performance. International Journal of Learning and Development Vol. 1, No. 1. 2011

[35] Marpaung, Marudut. Pengaruh Kepemimpinan dan Team Work terhadap Kinerja Karyawan di Koperasi Sekjen Kemedikbud Senayan Jakarta. Volume 2 Nomor 1. 2014

[36] Maxwell, John.Developing the Leader Within You Workbook..New York: Injoy, Inc.2001.

[37] MBAH.,Ifeyinwa,Stella. The Effects of Teamwork on Employees Performance : A Study of Selected Forms in Anambra State Nigeria. British Journal Of Advance Academic Research, Volume 3 Number 1. 2014

[38] McShane, Steven L., dan Glinow Von, Mary Ann.Organizational Behavior. 3rd edition. McGrawHill. USA.2005.

[39] Moorhead, Gregory dan Ricky W. Griffin. Perilaku Organisasi. Jakarta: Salemba Empat.2013.

[40] Mulyasa. Manajemen Berbasis Sekolah, Konsep, strategi dan Implementasi. Bandung : PT Remaja Rosdakarya. 2011

[41] Nanus, Burt. Kepemimpinan Visioner.Jakarta: Prehalindo. 2001

[42] Permadi, Dadi dan Arifin, Daeng. 2007. Kepemimpinan Transformasional Kepala sekolah dan Komite Sekolah. Bandung: PT. Sarana panca Karya Nusa.

[43] Rivai, Veithzal dan Basri, Ahmad Fawzi Mohd. Performance Appraisal. Jakarta Rajawali Pres. 2011.

[44] Rivai, Veithzal. Manajemen SDM untuk Perusahaan. Jakarta: Raja Grafindo Persada. 2004.

[45] Robbins, Stephen P dan Coulter. Manajemen. Jakarta: PT Indeks Kelompok Gamedia, 2004.

[46] Robbins, Stephen P. and Timothy A. Judge, Organizational Behavior, twelfth edition, New Jersey: Pearson, Prentice Hall, 2007.

[47] Robbins, Stephen P. Perilaku Organisasi, Jakarta: PT. Indeks Kelompok Gramedia, 2006.

[48] Robert W.B. Tehe Anonymyity Factor in Making Multicultural Teams Work: Virtual and Real Teams: http//www.sagepub.com/journalPermission.nav.2012

[49] Rusyan Tabrani, et all. Upaya meningkatkan Budaya Kinerja Guru. Cianjur: Dinamika Karya Cipta.2000

[50] Sagala, Syaiful. Memahami Organisasi Pendidikan. Bandung: Alfabeta, 2009. Schermerhorn, John D., James G Hunt, Richard N Osborn.Organizational

[51] Behaviour.John Willey and Son Inc.2005

[52] Schermerhorn, John R, James G Hunt, Richard N Osborn and Uhl- Bien,Mary.Organizational Behaviour.11 th Edition. New Jersey: John Willy and Sons. 2011

[53] Sedarmayanti. Good Governance (Kepemerintahan Yang Baik) Dalam Rangka Otonomi Daerah: Upaya Membangun Organisasi Efektif dan Efisien. Bandung: CV Mandar Maju. 2008. 


\section{DOI: $10.51386 / 25815946 / \mathrm{ijsms}-\mathrm{v} 4 \mathrm{i} 5 \mathrm{p} 117$}

Volume: 4 Issue: 5

September to October 2021

https://www.ijsmsjournal.org

[54] Sheng,C., Tian, Y., Chen, M.2010. Relationships Among Teamwork Behavior, Trust, Perceived Team Support, and Team Commitment.International Journal of Social Behavior and Personality Vol. 10, No. 38.

[55] Siregar, Z., Suhendro, D. 2019. "Pengaruh Disiplin Belajar, Kepribadian, dan Profesionalitas Guru Terhadap Kinerja Guru di SMP Negeri 10 Pematangsiantar”. Jurnal Akuntabilitas Manajemen Pendidikan, Vol. 7, No. 2, September 2019.

[56] Manajemen Sumber Daya Manusia. Jakarta: Grasindo.2008. Sopiah. Perilaku Organisasi, Yogyakarta: Andi Offset. 2008

[57] Sugiyono. Metodologi Penelitian Administrasi. Bandung: Alfa Beta. 2004.

[58] Tannenbaum, R. J., Weschler, I. R., \& Massarik, F. 1961. Leadership and organization: A behavioral science approach. McGraw-Hill.

[59] Terry, George R. 2009. Prinsip-prinsip Manajemen. Jakarta: Penerbit Bumi Aksara.

[60] Timothy A. Judge and Stephen P Robbins, Perilaku Organisasi, Edisi ke-12, Jakarta: Salemba Empat, 2008

[61] Usman, Husaini. MANAJEMEN (Teori, Praktek, dan Riset Pendidikan). Jakarta:Bumi Aksara. 2010

[62] Usman, Husaini.Manajemen Teori, Praktik, dan Riset Pendidikan.Jakarta:Bumi Aksara.2011.

[63] Wahjosumidjo. Kepemimpinan Kepala Sekolah, Edisi 1, Cetakan 7. Jakarta : PT. RajaGrafindo Persada. 2010.

[64] Wahyudi. Kepemimpinan Kepala Sekolah Dalam Organisasi Pembelajaran.Bandung:Alfabeta. 2009

[65] West, Michael. Kerja Sama yang Efektif. Cetakan Kelima. Penerjemah: Srikandi Waluyo. Yogyakarta: Penerbit Kanisius. 2002

[66] Wibowo. Manajemen Kinerja. PT. Raja Grafindo Persada: Jakarta. 2009

[67] Wibowo, Agus \& Gunawan Pendidikan Karakter Berbasis Kearifan Lokal di Sekolah.Yogyakarta: Penerbit Pustaka Belajar. 2015

[68] irawan, Kepemimpinan: Teori, Psikologi, Perilaku Organisasi, Aplikasi dan Penelitian, Jakarta, Rajawali Pers, 2014

[69] Yamin, Martinis dan Maisah. Standarisasi Kinerja Guru. Jakarta: Persada Press.2010

[70] Yaverbaum, E. \& Sherman, E.2008. Everything Leadership Book. 2 nd Edition.

[71] Avon, Massachusetts: Adams Media.

[72] Yukl, Gary. Kepemimpinan dalam Organisasi. Edisi Kelima. Jakarta:PT. Indeks.2010. 